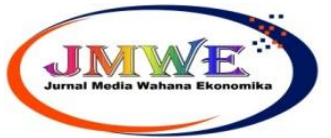

IS.SN 16.9.3-40.91 F-IS.SN 26ว?-1845

https://jurnal.univpgri-palembang.ac.id/index.php/Ekonomika/index

\title{
Pengaruh Gaya Kepemimpinan, Lingkungan Kerja dan Stres Kerja Terhadap Kinerja Pegawai Pada Dinas Ketahanan Pangan Dan Peternakan Kota Palembang
}

\author{
Benny Usman ${ }^{1}$, Edduar Hendri ${ }^{2}$, Lusi Suryadi ${ }^{3}$ \\ ${ }^{1}$ Fakultas Ekonomi dan Bisnis Universitas PGRI Palembang, benny usman@univpgri-palembang.ac.id \\ ${ }^{2}$ Fakultas Ekonomi dan Bisnis Universitas PGRI Palembang, hendri edduar@yahoo.com \\ ${ }^{3}$ Fakultas Ekonomi dan Bisnis Universitas PGRI Palembang, lusisuryadi317@gmail.com
}

\begin{abstract}
ABSTRAK
Penelitian ini bertujuan untuk mengetahui dan menguji ada atau tidaknya pengaruh Gaya Kepemimpinan, Lingkungan Kerja Dan Stres Kerja Terhadap Kinerja Pegawai Pada Dinas Ketahanan Pangan Dan Peternakan Kota Palembang. Teknik pengumpulan data dalam penelitian ini melalui wawancara dan Penyebaran Kusioner. Sampel yang digunakan dalam penelitian ini menggunakan teknik Probabilitas Sampling sehingga diperoleh sampel sebanyak 51 pegawai. Teknik analisis data menggunakan uji asumsi klasik, analisis regresi liniar berganda, koefisien determinasi, pengujian hipotesis uji $\mathrm{T}$ dan uji $\mathrm{F}$. Hasil penelitian ini dapat diketahui bahwa nilai persamaan regresi linear berganda $Y=4,849+0,361 X_{1}+0,686 X_{2}-0,202 X_{3}$. Hasil koefisien determinasi menunjukkan nilai $R$ Square sebesar 0,837 artinya pengaruh variabel-variabel bebas (Gaya Kepemimpinan $X_{1}$, Lingkungan Kerja $X_{2}$ dan Stres Kerja $X_{3}$ ) terhadap variabel terikat (Kinerja Pegawai) sebesar 83,7\% sedangkan sisanya $17,3 \%$ dipengaruhi oleh variabel yang lain yang tidak diteliti didalam penelitian. Hasil pengujian hipotesis uji $T$ Gaya Kepemimpinan $X_{1}$ terhadap kinerja pegawai $(Y)$ diperoleh nilai signifikan 0,000 > 0,05 maka dapat disimpulkan secara parsial ada pengaruh yang signifikan terhadap kinerja pegawai. Hasil pengujian hipotesis uji t Lingkungan Kerja $\mathrm{X}_{2}$ terhadap kinerja pegawai $(\mathrm{Y})$ diperoleh nilai signifikan $0,000<0,05$ maka disimpulkan secara parsial ada pengaruh signifikan terhadap Kinerja Pegawai. Hasil pengujian hipotesis uji t Stres Kerja $X_{3}$ terhadap terhadap kinerja pegawai $(Y)$ diperoleh nilai signifikan 0,008 < 0,05 maka dapat disimpulkan bahwa stres kerja berpengaruh signifikan terhadap Kinerja Pegawai. Hasil pengujian hipotesis uji $F$ diperoleh nilai signifikan $0,000<0,05$ maka Ho ditolak dan Ha diterima, maka dapat disimpulkan bahwa (Gaya Kepemimpinan $X_{1}$, Lingkungan Kerja $X_{2}$ dan Stres Kerja $X_{3}$ ) secara bersama-sama ada pengaruh yang signifikan terdapat Kinerja Pegawai (Y) Dinas Ketahanan Pangan dan Peternakan Kota Palembang.
\end{abstract}

Kata Kunci: Gaya Kepemimpinan, Lingkungan Kerja, Stres Kerja, Kinerja Pegawai

\begin{abstract}
This research aims to know and test whether or not the influence of leadership style, working environment and occupational stress to the performance of employees at the Department of Food Security and livestock in Palembang. Data collection techniques in this study through interviews and dissemination of Kusioner. The samples used in this study were using probability Sampling techniques so that samples were obtained by 51 employees. Data analysis techniques using classical assumption tests, multiple liniar regression analyses, coefficient of determination, $T$ test hypothesis testing and $F$ test. The results of this study can be noted that the value of double linear regression equation $Y=$ $4.849+0,361 \times 1+0.686 \times 2-0.202 \times 3$. The result of the coefficient of determination indicates that the $R$ Square value of 0.837 means that the influence of free variables (the $X 1$ leadership style, the work environment X2 and the work stress $X 3$ ) of the bound variable (employee performance) amounted to $83.7 \%$ while the remaining $17.3 \%$ is influenced by other variables not examined in the study. The test result of the $T$-style leadership test hypothesis $X 1$ on the employee's performance $(Y)$ obtained a significant value $0.000>0.05$ can be deduced in partial there is a significant influence on the employee's performance. Testing results of T-Test hypothesis X2 work environment on personnel performance $(Y)$ obtained a significant value of $0.000<0.05$ then concluded partially there is a significant influence on the employee's performance. Testing results of $T$ test hypothesis the work stress $X 3$ against the employees ' performance $(Y)$ obtained a significant value of $0.008<0.05$ then it
\end{abstract}


can be concluded that the work stress has significant effect on the employee's performance. Test results of the F testing hypothesis obtained a significant value of $0.000<0.05$ then $\mathrm{Ho}$ rejected and $\mathrm{Ha}$ accepted, it can be concluded that (style leadership X1, working environment X2 and Work stress X3) jointly there is a significant influence there is the personnel performance $(Y)$ Department of Food Security and livestock farming Palembang.

Keywords: leadership style, work environment, occupational stress, employee performance

\section{A. PENDAHULUAN}

Dalam mendukung pencapaian tujuan suatu organisasi maka diperlukan sumber daya manusia yang kreatif dan inovatif. Pencapaian dari suatu tujuan organisasi umumnya terletak pada upaya bagaimana cara organisasi tersebut mengelola sumber daya manusia yang dimiliki menjadi berdaya guna.

Gaya kepemimpinan seseorang adalah pola prilaku yang diperlihatkan orang itu pada saat mempengaruhi aktivitas orang lain seperti yang dipersepsikan orang lain Harsey dan Blachard (dalam Prayatna dan Subudi 2017:47)

Lingkungan kerja itu adalah keadaan yang disekeliling kita yang mampu mempengaruhi diri kita dalam menjalankan kegiatan aktivitas kerja, suatu kondisi lingkungan kerja yang kurang baik berpotensis besar penyebab pegawai mudah stres dalam kerja, sulit untuk berkosentrasi dalam kerja dan lebih parahnya lagi menurunya produktivitas kerja pegawai. Secara prinsip jika ruangan kerja kurang nyaman seperti hal nya panas, pentilasi udara tidak ada, ruangan kerja yang sempit, lingkungan kerja yang bising, kebersihan wc yang selalu tidak terjaga, keamanan lingkungan yang kurang kondusif. Maka dari hal itu semua bisa mempengaruhi menurunnya kinerja seorang pegawai.

Bekerja adalah tuntutan hidup bagi seorang manusia dalam melakukan aktivitas kerja tubuh kita perlu juga istirahat, ketenangan, keharmonisan dalam kerja baik itu berhubungan dengan rekan kerja ataupun pimpinan. Akan tetapi jika semua itu tidak bisa kita rasakan maka dampak yang ditimbulkan dari itu semua adalah stres dalam kerja. Oleh sebab itu atasan harus mampu meminimalisir stres kerja terhadap para pegawainya seperti halnya tidak memberikan beban pekerjaan yang terlalu banyak terhadap bawahanya, sekali-kali memberikan loyalitas waktu liburan bersama-sama untuk pegawainya dan lain sebagainya.

Selain stres kerja yang perlu juga diperhatikan adalah kinerja para pegawai. Kinerja pegawai adalah keseluruhan kemampuan seseorang untuk berkerja sedemikian rupa sehingga mencapai tujuan kerja secara optimal dan berbagai sasaran yang telah diciptakan dengan pengorbanan yang secara rasio lebih kecil dibanding dengan hasil yang dicapai. Kinerja dari seorang pimpinan maupun kinerja para bawahanya mempunyai kinerja yang baik akan diperoleh ketika unit-unit kegiatan dari atasan itu terlaksanan dengan efektif dan efisien. Dengan kata lain, dimana bawah kinerja itu merujuk pada tingkat keberhasilan dalam melaksanakan tugas serta kemampuan untuk mewujudkan tujuan daripada instansi yang telah ditentukan sebelumnya. oleh karena itu suatu instansi selalu mengharapkan bisa memiliki pegawai yang mempunyai prestasi, karena dengan mempunyai pegawai yang berprestasi akan memberikan dampak yang positif bagi instansi, dengan kata lain kemajuan dari instansi itu ditentukan oleh kinerja para pegawainya.

\section{B. KAJIAN TEORI}

1. Gaya Kepemimpinan

Menurut Rivai. V dalam Sudaryono (2017:172) Gaya kepemimpinan adalah 
pola menyeluruh dari tindakan seseorang pemimpin, baik yang tampak maupun yang tidak tampak oleh bawahannya. Gaya Kepemimpinan menggambarkan kombinasi yang konsisten dari falsafah keterampilan sifat dan sikap yang mendasari perilaku seseorang.

Menurut Filppo dalam Sudaryono (2017:172) berpendapat Gaya Kepemimpinan dapat dirumuskan sebagai suatu pola prilaku yang dirancang untuk memadukan kepentingan-kepentingan organisasi dan personalia guna mengejar beberapa sasaran. Menurut Harsey dan Blanchrd dalam Prayatna dan Subudi (2016:47) gaya kepemimpinan adalah pola prilaku yang diperlihatkan seseorang itu pada saat mempengaruhi aktivitas orang lain seperti yang dipersepsikan orang lain.

\section{Lingkungan Kerja}

Kinerja seorang pegawai dipengaruhi oleh banyak faktor diantarannya adalah penempatan posisi jabatan yang tidak sesuai, tidak pernah ada keharmonisan sesama pegawai dan banyak lagi faktor lainya. Selain faktor tersebut ada faktor lain yang juga dapat mempengaruhi kinerja pegawai dalam melaksanakan tugas-tugas kerja yaitu lingkungan kerja. Karena pada dasarnya lingkungan kerja yang memadai dapat menigkatkan kinerja pegawai, sedangkan lingkungan yang kurang memadai bagi pegawai dapat menurunkan kinerja pegawai. Lingkungan kerja fisik merupakan suatu lingkungan dimana para karyawan bekerja dan dapat mempengaruhi mereka dalam menjalankan tugas - tugas yang dibebankan. (Oktariansyah, 2012:80).

Sedarmayanti dalam Sudaryono (2018:60) menyatakan lingkungan kerja adalah keseluruhan alat peraksa dan bahan yang dihadapi lingkungan sekitarnya dimana seseorang berkerja, metode kerjanya serta pengaturan kerjannya sebagai perorangan maupun kelompok. Oleh kerena itu, lingkuan kerja merupakan keadaan sekitar tempat kerja, baik secara fisik maupun non fisik yang dapat memberikan kesan yang menyenangkan, mengamankan dan menentramkan. Kondisi lingkungan kerja yang baik akan membuat pegawai merasa nyaman dalam berkerja. Kesan yang nyaman akan lingkungan kerja dimana akan pegawai tersebut berkerja akan mengurangi rasa kejenuhan dan kebosanan dalam berkerja. Kenyamanan tersebut tentunya akan berdampak pada kinerja pegawai.

\section{Stres Kerja}

Stres ditempat kerja adalah sebuah masalah kritis yang mangkin bertambah bagi para pekerja, majikan dan masyarakat. Stres ditempat kerja merupakan perhatian yang tumbuh pada keadaan ekonomi sekarang, dimana para pegawai menemui kondisi-kondisi kelebihan kerja, ketidak nyamanan kerja, tingkat kepuasan kerja yang rendah, ketidak otonomi.

Invanko dalam Hamali.Y.A. (2016:241) Stres biasanya didefinisikan dengan kondisi-kondisi internal dan eksternal yang menciptakan situasi-situasi yang penuh dengan tekanan. Gibson dkk dalam Septianto Dwi menyatakan stres kerja adalah suatu tanggapan dalam penyesuaian di perantarai oleh perbedan-perbedaan individu dan proses fisikologi yang merupakan suatu konsekuensi dari setiap tindakan dari luar (lingkungan) situasi atau peristiwa yang menetapkan permintaan fisikologis dan atau fisik berkelebihan kepada seorang.

Hasibuan.S.P. (2013:204) mendefinisakan stres kerja adalah suatu kondisi ketegangan yang mempengaruhi emosi, proses berpikir, dan kondisi seseorang. Orang-orang yang mengalami stres menjadi nevous dan merasakan kehawatiran kronis. Mereka sering menjadi marah-marah, agresif, dan tidak dapat relaks, atau memperlihatkan sifat yang tidak kooperatif. Yan Huanmin dalam Sari (2017:37) 
menyatakan stres kerja adalah salah satu masalah umum yang di hadapi karyawan dengan frekuensi yang meningkat.

\section{Kinerja Pegawai}

Wibowo (2016:3) mendefinisika kinerja adalah merupakan implementasi dari rencana yang telah disusun tersebut. Implementasi kinerja dilakukan oleh sumber daya manusia yang memiliki kemampuan, kompentensi, kempuan, motivasi, dan kepentingan.

Gibson dalam Wibowo (2016:2) kinerja pegawai adalah hasil dari perkerjaa yang berkaitan dengan tujuan organisasi seperti kualitas, efisiensi dan kriteria lain dan efektivitas.

Miner dalam Sutrisno Edy (2011:170) kinerja adalah bagaimana seseorang diharapkan dapat berfungsi dan berprilaku sesuai dengan tugas yang telah dibebankan kepadanya.

Sari dalam Nurhidaya Siti (2018:32) kinerja karyawan merupakan suatu hasil prestasi kerja karyawan yang dinilai dari segi kualitas atau kuantitas berdasarkan standar kerja yang di tentukan oleh pihak perusahaan.

\section{Hipotesis Penelitian}

Sugiyono (2018:134) hasil yang didapatkan untuk sementara terhadap penelitian masalah, dimana rumusan masalah itu telah ditetapkan dalam kalimat pertanyaan yang dengan kata lain disebut hipotesis. Dalam kaitanya dengan pengaruh Gaya Kepemimpinan, Lingkungan Kerja dan Stres Kerja Terhadap Kinerja Pegawai, maka rumusan hipotesis adalah:

$\mathbf{H}_{\mathbf{1}}$ : Diduga ada Pengaruh Gaya Kepemimpinan Terhadap Kinerja Pegawai pada Kantor Badan Ketahanan Pangan dan Peternakan Kota Palembang.

$\mathbf{H}_{\mathbf{2}}$ : Diduga ada Pengaruh Lingkungan Kerja Terhadap Kinerja Pegawai Pada Kantor Badan Ketahanan Pangan dan Peternakan Kota Palembang.

$\mathbf{H}_{3}$ : Diduga ada Pengaruh Stres Kerja Terhadap Kinerja Pegawai Pada Kantor Badan Ketahan Pangan dan Peternakan Kota Palembang.

$\mathbf{H}_{\mathbf{4}}$ : Diduga ada Pengaruh Gaya Kepemimpinan, Lingkungan Kerja dan Stres Kerja Terhadap Kinerja Pegawai Pada Kantor Badan Ketahanan Pangan dan Peternakan Kota Palembang.

\section{METODE PENELITIAN} kuantitatif.

Metode penelitian yang digunakan adalah metode penelitian asosiatif

Populasi dalam penelitian ini yaitu seluruh total pegawai Dinas Ketahanan Pangan dan Peternakan Palembang dan Sampel yang menjadi responden dalam penelitian ini disesuaikan menjadi sebanyak 51 orang dari seluruh total pegawai Dinas Ketahanan Pangan dan Peternakan Palembang, hal ini ditentukan untuk mempermudah dalam pengelolaan data dan untuk hasil pengujian yang lebih baik.

Sumber data menurut perolehannya sebagai berikut:

1. Data primer

Merupakan hasil dari wawancara peneliti dengan narasumber yang diperoleh dari kusioner melalui responden atau kelompok. Data yang diperoleh dari data primer ini harus diolah lagi. Sumber data yang langsung memberikan data kepada pengumpul data.

2. Data Sekunder

Data sekunder adalah merupakan data yang diperoleh dari buku sebagai teori, 
majalah, laporan pemerintah, catatan, laporan keuangan, publikasi perusahaan dan lain sebagainya. Data yang diperoleh dari data sekunder ini tidak perlu diolah lagi. Sumber yang tidak langsung memberikan data pada pengumpulan data.

Teknik Pengumpulan Data yang dilakukan yaitu dengan cara :

1. Kuesioner (Angket)

Sugiyono (2018:230) kusioner merupakan teknik pengumpulan data yang dilakukan dengan cara memberi seperangkat pertanyaan atau pernyataan tertulis kepad responden untuk dijawabnya.

2. Wawancara.

Wawancara adalah teknik pengumpulan data jika peneliti atau pengumpul data sudah mengetahui dengan pasti prihal informasi apa yang akan diperoleh, dengan demikian dalam melakukan wawancara peneliti telah menyiapkan instrumen penelitian berupa pernyataan-pernyataan tertulis yang dialternatifkan jawabannya sudah disiapkan.

\section{Uji Asumsi Klasik}

\section{Uji Normalitas}

Gozali dalam Sujarweni (2019:225) menyatakan uji normalitas bertujuan untuk menguji apakah dalam model regresi, variabel terikat dan variabel bebaskeduannya mempunyai distribusi normal ataukah tidak. Uji normalitas data dapat dilakukan dengan menggunakan uji Kolmogorov Smirnov satu arah dengan tariff seignifikan 0,05. Dasar penarikan kesimpulan $p$-Kolmogorov - Semirnov test $>0.05$.

Hipotesis:

$\mathrm{H}_{\mathrm{o}}=$ Sampel berasal dari distribusi data normal

$\mathrm{H}_{\mathrm{a}}=$ Sampel berasal dari populasi berdistribusi tidak normal.

2. Uji Multikolinearitas.

Uji multikolonearitas di perlukan untuk mengetahui ada tidaknya variabel independen yang memiliki kemiripan antar variabel independen dalam suatu model. Gozali dalm Sujarweni (2019:176) kemiripan antar variabel independen akan mengakibatkan korelasi yang sangat kuat. Selain itu untuk uji ini juga untuk menghindari kebiasaan dalam proses pengambilan keputusan mengenai pengaruh pada uji persial masing-masing variabel independen terhadap variabel dependen. Pendeteksian keberadaan multikolinearitas dapat dilihat dari nilai Tolerance dan lawanya Variance Inflation Factor (VIF). Kedua ukuran ini menunjukan variabel independen manakah yang dijelaskan oleh variabel independenlainnya. Apakah nilai Tolerance $>0,1$ dan VIF $<10$, maka dapat disimpulkan bahwa model regresi bebas dari multikolinearitas.

3. Uji Heterokedasitas.

Uji heterokedasitas dapat dilakukan dengan menggunakan uji Glejser yaitu dengan menguji tingkat signifikansinya. Gozali dalam Sujarweni (2019:226) penguji ini dilakukan untuk merespon variabel $X$ sebagai variabel penden. Apabila hasil uji diatas level signifikan $(r>0,05)$ berarti tidak terjadi heterokedasitas. Uji ini dilakukan dengan meregresikan variabel independen terhadap nilai absolut residual. 


\section{Krieteria Penguji Hipotesis}

1. Uji t (secara persial)

Sujarweni (2019:161) uji t adalah cara seseorang atau individu penguji regresi persial yang digunakan untuk mengetahui apakah independen $(x)$ secara individu mempengaruhi variabel dependen (y).

Kriteria penerimaan dan penolakan hipotesis sebagai berikut:

a. Jika Sig $<0,05$ maka $\mathrm{H}_{0}$ ditolak dan $\mathrm{H}_{\mathrm{a}}$ diterima

b. Jika Sig > 0,05 maka $\mathrm{H}_{0}$ diterima dan $\mathrm{H}_{\mathrm{a}}$ ditolak

2. Uji f (secara simultan)

Sujarweni (2019:162) uji $f$ adalah penguji signifikan persamaan yang digunakan untuk mengetahui seberapa besar pengaruh varibael bebas $\left(X_{1}, X_{2}\right.$ dan $\left.X_{3}\right)$ secara bersama-sama terhadap variabel terikat $(\mathrm{Y})$. Dalam hal ini apakah variabel gaya kepemimpinan lingkungan kerja dan stres kerja berpengaruh secara signifikan atau tidak terhadap kinerja pegawai.

Kriteria penguji menggunakan tingkat signifikan 0.05 .

a. Jika Sig $<0,05$ maka $\mathrm{H}_{\circ}$ ditolak dan $\mathrm{H}_{\mathrm{a}}$ diterima

b. Jika Sig > 0,05 maka $\mathrm{H}_{0}$ diterima dan $\mathrm{H}_{\mathrm{a}}$ ditolak

\section{HASIL PENELITIAN}

\section{Uji Validitas Kuesioner}

Untuk menguji validitas kuesioner dalam penelitian ini digunakan rumus korelasi product moment yang dilakukan terhadap 51 responden pada saat survey sehingga diperoleh nilai $r_{\text {tabel }}$ dengan $\alpha=0,05$ yaitu 0,275 . Analisis validitas kuesioner meliputi variabel gaya kepemimpinan $\left(X_{1}\right)$, lingkungan kerja $\left(X_{2}\right)$, stres kerja $\left(X_{3}\right)$, dan kinerja pegawai $(Y)$. Adapun hasil uji validitas kuesioner dapat diketahui pada tabel-tabel di bawah ini:

Tabel Pengujian Validitas Kuesioner Variabel Gaya kepemimpinan $\left(\mathbf{X}_{1}\right)$

\begin{tabular}{cccc}
\hline Item & $\begin{array}{c}\text { Corrected Item- } \\
\text { Total Correlation }\end{array}$ & $\begin{array}{c}r_{\text {tabel }} \\
\text { (Taraf Kepercayaan 95\%) }\end{array}$ & Keterangan \\
\hline 1 & $0.439^{* *}$ & & Valid \\
2 & $0.471^{* *}$ & & Valid \\
3 & $0.825^{* *}$ & & Valid \\
4 & $0.839^{* *}$ & & Valid \\
5 & $0.384^{* *}$ & 0,275 & Valid \\
6 & $0.796^{* *}$ & & Valid \\
7 & $0.659^{* *}$ & & Valid \\
8 & $0.793^{* *}$ & & Valid \\
9 & $0.751^{* *}$ & Valid \\
10 & $0.811^{* *}$ & Valid \\
11 & $0.648^{* *}$ & & Valid \\
12 & $0.652^{* *}$ & Valid \\
\hline
\end{tabular}

Sumber: Data primer diolah, Tahun 2020

Berdasarkan tabel dapat diketahui bahwa nilai $\mathbf{r}_{\text {hitung }}$ korelasi product moment semua item pernyataan dari variabel gaya kepemimpinan $\left(X_{1}\right)$ lebih besar dari pada nilai kritis $\left(r_{\text {tabel }}\right)$ sebesar 0,275 pada tingkat kepercayaan $95 \%$. Dengan demikian, maka seluruh item pertanyaan variabel Gaya Kepemimpinan $\left(\mathrm{X}_{1}\right)$ dinyatakan valid dan dapat digunakan sebagai alat pengumpulan data. 


\begin{tabular}{|c|c|c|c|}
\hline \multicolumn{4}{|c|}{$\begin{array}{c}\text { Tabel Pengujian Validitas Kuesioner } \\
\text { Variabel Lingkungan Kerja }\left(\mathrm{X}_{2}\right)\end{array}$} \\
\hline Item & $\begin{array}{l}\text { Corrected Item- } \\
\text { Total Correlation }\end{array}$ & $\begin{array}{c}r_{\text {tabel }} \\
\text { (Taraf Kepercayaan 95\%) }\end{array}$ & Keterangan \\
\hline 1 & $0.361^{* *}$ & & Valid \\
\hline 2 & $0.816^{* *}$ & & Valid \\
\hline 3 & $0.730^{* *}$ & & Valid \\
\hline 4 & $0.549^{* *}$ & & Valid \\
\hline 5 & $0.640^{* *}$ & & Valid \\
\hline 6 & $0.517^{* *}$ & 0,215 & Valid \\
\hline 7 & $0.688^{* *}$ & & Valid \\
\hline 8 & $0.676^{* *}$ & & Valid \\
\hline 9 & $0.663^{* *}$ & & Valid \\
\hline 10 & $0.571^{* *}$ & & Valid \\
\hline
\end{tabular}

Sumber: Data primer diolah, Tahun 2020

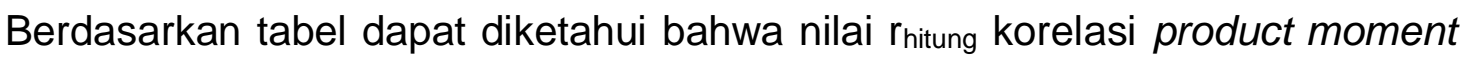
semua item pernyataan dari variabel lingkungan kerja $\left(\mathrm{X}_{2}\right)$ lebih besar dari pada nilai kritis ( $\left.r_{\text {tabel }}\right)$ sebesar 0,275 pada tingkat kepercayaan $95 \%$. Dengan demikian, maka seluruh item pertanyaan variabel lingkungan kerja $\left(\mathrm{X}_{2}\right)$ dinyatakan valid dan dapat digunakan sebagai alat pengumpulan data.

\begin{tabular}{|c|c|c|c|}
\hline \multicolumn{4}{|c|}{$\begin{array}{c}\text { Tabel Pengujian Validitas Kuesioner } \\
\text { Variabel Stres Kerja }\left(\mathbf{X}_{3}\right)\end{array}$} \\
\hline Item & $\begin{array}{c}\text { Corrected Item- } \\
\text { Total } \\
\text { Correlation }\end{array}$ & $\begin{array}{c}r_{\text {tabel }} \\
\text { (Taraf Kepercayaan 95\%) }\end{array}$ & Keterangan \\
\hline 1 & $0.516^{* *}$ & & Valid \\
\hline 2 & $0.485^{* *}$ & & Valid \\
\hline 3 & $0.883^{* *}$ & & Valid \\
\hline 4 & $0.905^{* *}$ & & Valid \\
\hline 5 & $0.407^{* *}$ & & Valid \\
\hline 6 & $0.835^{* *}$ & $0,2 / 5$ & Valid \\
\hline 7 & $0.765^{* *}$ & & Valid \\
\hline 8 & $0.834^{* *}$ & & Valid \\
\hline 9 & $0.719^{* *}$ & & Valid \\
\hline 10 & $0.842^{* *}$ & & Valid \\
\hline
\end{tabular}

Sumber: Data primer diolah, Tahun 2020

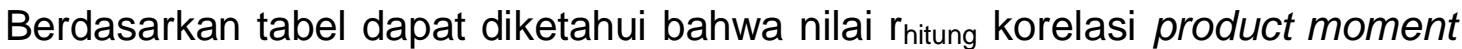
semua item pernyataan dari variabel stres kerja $\left(\mathrm{X}_{3}\right)$ lebih besar dari pada nilai kritis $\left(r_{\text {tabel }}\right)$ sebesar 0,275 pada tingkat kepercayaan 95\%. Dengan demikian, maka seluruh item pertanyaan variabel stres kerja $\left(X_{3}\right)$ dinyatakan valid dan dapat digunakan sebagai alat pengumpulan data. 


\begin{tabular}{|c|c|c|c|}
\hline Item & $\begin{array}{c}\text { Corrected Item- } \\
\text { Total } \\
\text { Correlation }\end{array}$ & $\begin{array}{c}r_{\text {tabel }} \\
\text { (Taraf Kepercayaan 95\%) }\end{array}$ & Keterangan \\
\hline 1 & $0.672^{*}$ & & Valid \\
\hline 2 & $0.632^{*}$ & & Valid \\
\hline 3 & $0.763^{* *}$ & & Valid \\
\hline 4 & $0.716^{* *}$ & & Valid \\
\hline 5 & 0.627 & & Valid \\
\hline 6 & $0.791^{\star *}$ & 0,275 & Valid \\
\hline 7 & $0.750^{\star *}$ & & Valid \\
\hline 8 & $0.599^{* *}$ & & Valid \\
\hline 9 & $0.641^{* *}$ & & Valid \\
\hline 10 & $0.476^{\star *}$ & & Valid \\
\hline 11 & $0.828^{* *}$ & & Valid \\
\hline 12 & $0.680^{* *}$ & & Valid \\
\hline
\end{tabular}

Sumber: Data primer diolah, Tahun 2020

Berdasarkan tabel dapat diketahui bahwa nilai $r_{\text {hitung }}$ korelasi product moment dari seluruh item variabel kinerja pegawai $(\mathrm{Y})$ lebih besar dari pada nilai kritis $\left(r_{\text {tabel }}\right)$ sebesar 0,275 pada tingkat kepercayaan $95 \%$. Dengan demikian, maka seluruh item pertanyaan variabel kinerja pegawai $(\mathrm{Y})$ dinyatakan valid dan dapat digunakan sebagai alat pengumpulan data.

\section{Uji Reliabilitas Kuesioner}

Untuk menguji reliabilitas kuesioner atau pertanyaan digunakan rumus cronbach alpha, dengan syarat dinyatakan reliabel apabila nilai rhitung lebih besar dari pada nilai $r_{\text {tabel. }}$. Hasil pengujian reliabilitas kuesioner dapat dilihat dibawah ini:

Tabel Pengujian Reliabilitas Kuesioner

\begin{tabular}{cccc}
\hline Variabel & $\begin{array}{c}\text { Nilai } \\
\text { Reliabilitas }\end{array}$ & $\begin{array}{c}\text { rtabel } \\
\text { (Taraf Kepercayaan 95\%) }\end{array}$ & Keterangan \\
\hline $\mathrm{X}_{1}$ & 0.879 & & Reliabel \\
$\mathrm{X}_{2}$ & 0.815 & & Reliabel \\
$\mathrm{X}_{3}$ & 0.884 & 0,275 & Reliabel \\
$\mathrm{Y}$ & 0.782 & & Reliabel \\
\hline
\end{tabular}

Sumber: Data primer diolah, Tahun 2020

Berdasarkan tabel diketahui bahwa nilai koefisien reliabilitas untuk variabel gaya kepemimpinan $\left(X_{1}\right)$, lingkungan kerja $\left(X_{2}\right)$, stres kerja $\left(X_{3}\right)$, dan kinerja pegawai $(Y))$ lebih besar dari pada nilai kritis $\left(r_{\text {tabel }}\right)$ sebesar 0,275 sehingga semua variabel tersebut dinyatakan reliabel dan dapat digunakan sebagai alat pengumpulan data.

\section{Uji Normalitas}

Uji normalitas bertujuan menguji apakah dalam model regresi variabel terikat dan variabel bebas keduanya mempunyai distribusi normal atau tidak, maka untuk menguji apakah data penelitian ini terdistribusi normal atau tidak dapat dideteksi melalui dua cara yaitu analisis grafik dan analisis statistik (uji One Sample Kolmogorov Smirnov). Dalam penelitian ini uji normalitas dilakukan dengan uji One Sample Kolmogorov Smirnov dengan hasil sebagai berikut: 


\section{Tabel One-Sample Kolmogorov-Smirnov Test}

\begin{tabular}{|c|c|c|}
\hline & & $\begin{array}{l}\text { Unstandardized } \\
\text { Residual }\end{array}$ \\
\hline $\mathrm{N}$ & & 51 \\
\hline \multirow[t]{2}{*}{ Normal Parameters ${ }^{a, b}$} & Mean & .0000000 \\
\hline & $\begin{array}{l}\text { Std. } \\
\text { Deviation }\end{array}$ & .65441201 \\
\hline Extreme & Absolute & .249 \\
\hline Differences & $\begin{array}{l}\text { Positive } \\
\text { Negative }\end{array}$ & $\begin{array}{l}.249 \\
-.222\end{array}$ \\
\hline Test Statistic & & .249 \\
\hline Asymp. Sig. (2-tailed) & & .446 \\
\hline
\end{tabular}

Berdasarkan tabel menjelaskan bahwa nilai Asymp. Sig. (2-tailed) sebesar 0,446 Seperti diketahui bahwa apabila nilai Asymp. Sig. (2-tailed) > 0,05 maka data berdistribusi normal, dan sebaliknya apabila nilai Asymp. Sig. (2-tailed) $<0,05$ maka data tidak berdistribusi normal. Dengan demikian, data seluruh variable berdistribusi normal.

\section{Uji Multikolinearitas}

Pengujian multikolinearitas dilakukan untuk melihat apakah pada model regresi ditemukan adanya korelasi antar variabel bebas. Model regresi yang baik seharusnya tidak terjadi multikolinearitas. Cara mendeteksinya adalah dengan melihat nilai Variance Inflation Factor (VIF). Menurut Gujarati (2012:23), pada umumnya jika VIF variabel bebas $<10$ dan nilai tolerance $>0,1$, maka variabel bebas tersebut tidak mempunyai persoalan multikolinearitas dengan variabel bebas lainnya. Hal tersebut terdapat pada tabel berikut ini :

Tabel Pengujian Multikolinearitas Coefficients $^{a}$

\begin{tabular}{|c|c|c|c|c|c|c|c|}
\hline \multirow[b]{2}{*}{ Model } & \multicolumn{3}{|c|}{$\begin{array}{ll}\text { Unstandardized } & \text { Standardized } \\
\text { Coefficients } & \text { Coefficients }\end{array}$} & \multirow[b]{2}{*}{$\mathrm{T}$} & \multirow[b]{2}{*}{ Sig. } & \multicolumn{2}{|c|}{$\begin{array}{l}\text { Collinearity } \\
\text { Statistics }\end{array}$} \\
\hline & B & $\begin{array}{l}\text { Std. } \\
\text { Error }\end{array}$ & Beta & & & Tolerance & VIF \\
\hline 1 (Constant) & 4.849 & 3.253 & & 1.491 & .143 & & \\
\hline Gaya & .361 & .086 & .423 & 4.218 & .000 & .345 & 2.895 \\
\hline Lingkungan & .686 & .129 & 541 & 5.319 & .000 & .336 & 2.979 \\
\hline Stres Kerja & -.202 & .061 & -.002 & 3.037 & .008 & .944 & 1.059 \\
\hline
\end{tabular}

a. Dependent Variable: Kinerja Pegawai

Sumber: Data primer diolah, Tahun 2020

Berdasarkan tabel dapat diketahui nilai variance inflation factor (VIF) variabel yaitu Gaya kepemimpinan $\left(X_{1}\right)$ sebesar 2,892, Lingkungan Kerja $\left(X_{2}\right)$ sebesar 2,979, dan Stres $\operatorname{Kerja}\left(X_{3}\right)$ sebesar 1,059 lebih kecil dari 10 dan nilai Tolerance variabel yaitu Gaya Kepemimpinan $\left(X_{1}\right)$ sebesar 0,345, Lingkungan Kerja $\left(X_{2}\right)$ sebesar 0,336, dan 
Stres Kerja $\left(X_{3}\right)$ sebesar 0,944 besar dari 0,100 , sehingga bisa disimpulkan bahwa antar variabel independen tidak terjadi persoalan multikolinearitas.

\section{Uji Heteroskedastisitas}

Uji heteroskedastisitas digunakan untuk mengetahui apakah dalam sebuah model regresi linier terjadi ketidaksamaan varian residual dari satu pengamatan ke pengamatan lain. Pendeteksian heteroskedatisitas dilakukan dengan menggunakan uji glejser. Dalam penelitian ini peneliti menggunakan uji glejser untuk mengetahui apakah terjadi atau tidak terjadi gejala heteroskedastisitas pada model regresi. Dasar pengambilan keputusan dalam uji heteroskedastisitas dengan menggunakan uji glejser adalah sebagai berikut:

a. Jika nilai signifikansi (Sig.) lebih besar dari 0,05, maka kesimpulannya adalah tidak terjadi gejala heteroskedastisitas dalam model regresi.

b. Jika nilai nilai signifikansi (Sig.) lebih kecil dari 0,05, maka kesimpulannya adalah terjadi gejala heteroskedastisitas dalam model regresi.

Hasil uji heteroskedastisitas dapat dilihat pada tabel berikut ini:

Tabel Hasil Uji Heteroskedastisitas Menggunakan Uji Glejser Coefficients $^{a}$

\begin{tabular}{ccccccc}
\hline & \multicolumn{2}{c}{$\begin{array}{l}\text { Unstandardized } \\
\text { Coefficients }\end{array}$} & $\begin{array}{c}\text { Standardized } \\
\text { Coefficients }\end{array}$ & & \\
\cline { 2 - 5 } & Model & $\mathrm{B}$ & Std. Error & Beta & $\mathrm{t}$ & Sig. \\
\hline 1 (Constant) & -.183 & 1.369 & & -.134 & .894 \\
Gaya & .133 & .045 & .735 & & 2.951 & .068 \\
Lingkungan & .123 & .065 & .535 & & 1.851 & .066 \\
Stres & -.118 & .063 & -.468 & & -1.880 & .073 \\
\hline
\end{tabular}

a. Dependent Variable: Abs_RES

Berdasarkan output di atas diketahui nilai signifikansi (Sig.) untuk variabel Gaya kepemimpinan (X1) adalah 0,068, nilai signifikansi (Sig.) untuk variabel Lingkungan Kerja (X2) adalah 0,066, dan untuk nilai signifikansi (Sig.) variabel Stres Kerja ( $\left.\mathrm{X}_{3}\right)$ adalah 0,073 . Karena nilai signifikansi ketiga variabel bebas di atas lebih kecil dari 0,05 maka sesuai dengan dasar pengambilan keputusan dalam uji glejser, dapat disimpulkan bahwa tidak terjadi gejala heteroskedastisitas dalam model regresi.

\section{Hasil Regresi Linier Berganda}

Pengaruh variabel Gaya kepemimpinan $\left(\mathrm{X}_{1}\right)$ Lingkungan Kerja $\left(\mathrm{X}_{2}\right)$ dan Stres Kerja $\left(\mathrm{X}_{3}\right)$ terhadap Kinerja Pegawai $(\mathrm{Y})$ Dinas Ketahanan Pangan dan Peternakan Kota Palembang dianalisis dengan menggunakan model regresi linier berganda. Proses pengolahan data dilakukan dengan menggunakan program Statistical Package for the Social Science (SPSS) versi 22.0. Adapun hasil regresi linier berganda tersebut disajikan pada tabel berikut ini. 
Tabel Hasil Output Uji Regresi Linear Berganda Coefficients $^{a}$

\begin{tabular}{|c|c|c|c|c|c|c|c|}
\hline \multirow[b]{2}{*}{ Model } & \multicolumn{2}{|c|}{$\begin{array}{l}\text { Unstandardized } \\
\text { Coefficients }\end{array}$} & \multirow{2}{*}{$\begin{array}{l}\text { Standardized } \\
\text { Coefficients } \\
\text { Beta }\end{array}$} & \multirow[b]{2}{*}{$\mathrm{T}$} & \multicolumn{3}{|c|}{$\begin{array}{l}\text { Collinearity } \\
\text { Statistics }\end{array}$} \\
\hline & $B$ & Std. Error & & & Sig. & Tolerance & VIF \\
\hline 1 (Constant) & 4.849 & 3.253 & & 1.491 & .143 & & \\
\hline Gaya & .361 & .086 & .423 & 4.218 & .000 & .345 & 2.895 \\
\hline Lingkungan & .686 & .129 & .541 & 5.319 & .000 & .336 & 2.979 \\
\hline Stres Kerja & -.202 & .061 & -.002 & 3.037 & .008 & .944 & 1.059 \\
\hline
\end{tabular}

a. Dependent Variable: Kinerja Pegawai

Sumber: Data primer diolah, Tahun 2020

Berdasarkan tabel dapat dibuat persamaan regresi linier berganda seperti berikut:

$Y=4,849+0,361 X_{1}+0,686 X_{2}-0,202 X_{2}$

Dimana:

Konstanta $=4,849$

$\mathrm{X}_{1} \quad=$ Gaya kepemimpinan $(0,361)$

$\mathrm{X}_{2} \quad=$ Lingkungan Kerja $(0,686)$

$\mathrm{X}_{3} \quad=$ Stres Kerja $(-0,202)$

Berdasarkan hasil persamaan regresi linier berganda, maka dapat dianalisis sebagai berikut:

a. Koefisien regresi gaya kepemimpinan sebesar 0,361 berarti peeningkatan gaya kepemimpinan sebesar satu persen akan meningkatkan kinerja pegawai sebesar $36,1 \%$.

b. Koefisien regresi dari lingkungan kerja sebesar 0,686 berarti bahwa peningkatan lingkungan kerja sebesar satu persen akan meningkatkan kinerja pegawai sebesar $68,6 \%$.

c. Koefisien regresi dari stres kerja sebesar 0,202 berarti bahwa penurunan stres kerja sebesar satu persen akan meningkatkan kinerja pegawai sebesar $20,2 \%$.

\section{Hasil Uji t}

Uji parsial (uji-t) dilakukan untuk menguji signifikansi pengaruh variabel-variabel bebas (gaya kepemimpinan, lingkungan kerja dan stres kerja) secara parsial atau individual terhadap variabel terikat (kinerja pegawai) Dinas Ketahanan Pangan dan Peternakan Kota Palembang. Uji-t dalam penelitian ini digunakan untuk melakukan pengujian hipotesis dengan tingkat signifikansi $(\alpha=0.05)$. Uji-t ditunjukkan pada tabel sebagai berikut:

Tabel Uji t (Parsial)

\begin{tabular}{ccc}
\hline Variabel Independen & T hitung & Sig \\
\hline (Constant) & 1.491 & .143 \\
Gaya kepemimpinan (X1) & 4.218 & .000 \\
Lingkungan Kerja (X2) & 5.319 & .000 \\
Stres Kejra (X3) & 3.037 & .008 \\
\hline
\end{tabular}

a. Dependent Variable: Kinerja Pegawai (Y)

Sumber: Data primer diolah, Tahun 2020

Berdasarkan tabel di atas dapat diketahui ada pengaruh secara parsial variabelvariabel bebas terhadap variabel terikat sehingga didapat hasil penelitian pada pengujian hipotesis. 


\section{Uji Hipotesis Pertama}

$\mathrm{H}_{1}$ : Di duga ada pengaruh yang signifikan gaya kepemimpinan pada Kinerja Dinas Ketahanan Pangan Kota Palembang.

Berdasarkan Tabel tabel di atas menunjukkan bahwa nilai $t$ sebesar 4.218 dengan signifikansi $0,000>0,05$. Hasil penelitian ini membuktikan kebenaran hipotesis 1 (satu) atau gaya kepemimpinan berpengaruh signifikan terhadap kinerja pegawai dinas ketahanan pangan dan peternakan kota palembang.

2. Uji Hipotesis Kedua

$\mathrm{H}_{2}$ : Di duga ada pengaruh yang signifikan lingkungan kerja terhadap kinerja pegawai dinas ketahanan pangan dan peternakan kota palembang.

Berdasarkan Tabel di atas menunjukkan bahwa nilai $t$ sebesar 5.319 dengan signifikansi $0,000<0,05$. Hasil penelitian ini membuktikan kebenaran hipotesis 2 (dua) atau lingkungan kerja berpengaruh signifikan terhadap kinerja pegawai dinas ketahanan pangan dan peternakan kota Palembang.

3. Uji Hipotesis Ketiga

$\mathrm{H}_{3}$ : Di duga ada pengaruh yang signifikan stres kerja terhadap kinerja pengawai dinas ketahanan pangan dan peternakan kota palembang.

Berdasarkan tabel di atas menunjukkan bahwa nilai $t$ sebesar 3,037 dengan signifikansi $0,008<0,05$. Hasil penelitian ini membuktikan kebenaran hipotesis 3 (tiga) atau stres kerja berpengaruh signifikan terhadap kinerja pegawai dinas ketahanan pangan dan peternakan kota palembang.

\section{Hasil Uji F}

Uji $\mathrm{F}$ digunakan untuk menjelaskan variabel bebas (gaya kepemimpinan, lingkungan kerja dan stres kerja) secara bersama-sama atau simultan berpengaruh signifikan terhadap variabel terikat (kinerja pegawai). Uji $F$ ditunjukan untuk mengukur tingkat keberartian hubungan secara keseluruhan koefisien regresi dari variabel bebas terhadap variabel terikat dengan menentukan nilai uji $F$ dengan tabel ANOVA (analysis of variance) dan tingkat signifikansi.

\begin{tabular}{ccccccc}
\multicolumn{8}{c}{} & \multicolumn{5}{c}{$\begin{array}{c}\text { TABEL Uji F } \\
\text { ANOVA }\end{array}$} \\
\hline & Sum of & & Mean & \\
& Model & Squares & Df & Square & F & Sig. \\
\hline 1 & Regression & 757.358 & 3 & 252.453 & 80.504 & .000 \\
& Residual & 147.387 & 47 & 3.136 & & \\
& Total & 904.745 & 50 & & & \\
\hline
\end{tabular}

a. Dependent Variable: Kinerja Pegawai

b. Predictors: (Constant), Stres Kerja, Gaya Kepemimpinan , Lingkungan Kerja

Berdasarkan tabel di atas menunjukkan bahwa nilai $F_{\text {hitung }}$ untuk model regresi adalah 80,504 dengan tingkat signifikansi $0,000<0,05$ maka tingkat signifikansi model regresi lebih kecil dari taraf nyata. Hasil ini menunjukkan bahwa variabelvariabel bebas yaitu gaya kepemimpinan, lingkungan kerja dan stres kerja secara simultan mempunyai pengaruh signifikan terhadap variabel terikat yaitu kinerja pegawai.

\section{Koefisien Determinasi}

Untuk mengetahui besarnya pengaruh variabel gaya kepemimpinan, lingkungan 
kerja dan stres kerja terhadap variabel kinerja pegawai dapat dilihat pada tabel berikut ini:

Tabel Koefisien Determinasi

\section{Model Summary}

\begin{tabular}{|c|c|c|c|c|}
\hline Model & $\mathrm{R}$ & R Square & $\begin{array}{l}\text { Adjusted } \\
\text { Square }\end{array}$ & $\begin{array}{l}\text { R Std. Error of } \\
\text { the Estimate }\end{array}$ \\
\hline 1 & $.915^{\mathrm{a}}$ & .837 & .827 & 1.771 \\
\hline
\end{tabular}

Berdasarkan tabel di atas menjelaskan besarnya nilai korelasi/hubungan (R) yaitu sebesar 0,915 yang mengandung pengertian bahwa hubungan variabelvariabel bebas (gaya kepemimpinan, lingkungan kerja dan stres kerja) dengan variabel terikat (kinerja pegawai) termasuk dalam kategori kuat. Besarnya persentase pengaruh variabel-variabel bebas terhadap variabel terikat yang disebut koefisien determinasi yang merupakan hasil dari penguadratan $R$. Dari output tersebut diperoleh koefisien determinasi ( $R$ Square) sebesar 0,837 yang mengandung pengertian bahwa besarnya pengaruh variabel-variabel bebas (gaya kepemimpinan, lingkungan kerja dan stres kerja) terhadap variabel terikat (kinerja pegawai) sebesar $83,7 \%$ sedangkan sisanya $17,3 \%$ dipengaruhi oleh variabel yang lain yang tidak diteliti didalam penelitian ini.

\section{E. PEMBAHASAN}

\section{Pengaruh Gaya kepemimpinan terhadap Kinerja Pegawai}

Berdasarkan hasil uji regresi linier sederhana menunjukkan bahwa nilai $t$ sebesar 4.218 dengan signifikansi $0,000>0,05$. Hasil penelitian ini membuktikan kebenaran hipotesis 1 (satu) atau gaya kepemimpinan berpengaruh signifikan terhadap kinerja pegawai dinas ketahanan pangan dan peternakan kota palembang. Didukung oleh hasil penelitian Trang, (2013) yang menyatakan bahwa gaya kepemimpinan dan budaya organisasi pengaruhnya terhadap kinerja karyawan Hasil penelitian menunjukkan gaya kepemimpinan memiliki tingkat signifikansi sebesar 0,447 yang artinya gaya kepemimpinan berpengaruh terhadap kinerja karyawan namun tidak signifikan. Budaya organisasi signifikan artinya budaya organisasi memiliki pengaruh positif dan signifikan terhadap kinerja karyawan. Secara simultan gaya kepemimpinan dan budaya organisasi berpengaruh positif dan signifikan terhadap kinerja karyawan. Dengan adanya temuan dalam penelitian ini, sebaiknya gaya kepemimpinan yang ada di Perwakilan BPKP Provinsi Sulawesi Utara disesuaikan dengan situasi dan kondisi yang ada pada saat ini.

\section{Pengaruh Lingkungan Kerja terhadap Kinerja Pegawai}

Berdasarkan hasil uji regresi sederhana menunjukkan bahwa nilai $t$ sebesar 5.319 dengan signifikansi $0,000<0,05$. Hasil penelitian ini membuktikan kebenaran hipotesis 2 (dua) atau lingkungan kerja berpengaruh signifikan terhadap kinerja pegawai kinerja pegawai dinas ketahanan pangan dan peternakan kota palembang.. Hasil penelitian ini didukung oleh hasil penelitian yang dilakukan oleh Sofyan (2013) dengan judul Pengaruh Lingkungan Kerja Terhadap Kinerja Kerja Pegawai 
BAPPEDA. Hasil yang diperoleh bahwa koefisien Durbin-Watson bernilai 0,801 yang menunjukan bahwa lingkungan kerja berpengaruh terhadap kinerja pegawai Kantor BAPPEDA, dimana hasil uji Hipotesis menunjukkan bahwa Ho ditolak artinya ada pengaruh secara signifikan antara lingkungan kerja terhadap kinerja kerja pegawai pada BAPPEDA Kabupaten $X$, sehingga jelas bahwa produktifitas kerja sangat dipengaruhi oleh lingkingan kerja.

\section{Pengaruh Stres Kerja terhadap Kinerja Pegawai}

Berdasarkan hasil uji regresi berganda menunjukkan bahwa nilai $t$ sebesar 3,037 dengan signifikansi $0,008<0,05$. Hasil penelitian ini membuktikan kebenaran hipotesis 3 (tiga) atau stres kerja berpengaruh signifikan terhadap kinerja pegawai dinas ketahanan pangan dan peternakan kota palembang. Hasil penelitian ini didukung oleh hasil penelitian yang dilakukan oleh Wartono (2017) dengan judul Pengaruh stres kerja terhadap kinerja karyawan. Berdasarkan hasil penelitian menunjukan terdapat pengaruh yang signifikan yang sangat kuat atau positif antara stres kerja terhadap kinerja karyawan yang ditunjukan dengan koefisien korelasi sebesar 0,880 dan koefisien determinasi $77,44 \%$. Hal ini berarti stres kerja mempengaruhi kinerja sebesar $77,44 \%$ sisanya sebesar $22,56 \%$ dipengaruhi oleh faktor- faktor lain. Setelah dilakukan uji signifikansi didapat hasil 10,643 maka Ho ditolak dan Ha diterima artinya terdapat pengaruh signifikan antara stres kerja terhadap kinerja karyawan.

\section{Pengaruh Gaya kepemimpinan, Lingkungan Kerja dan Stres Kerja terhadap Kinerja Pegawai}

Hasil uji Anova menunjukkan bahwa nilai $F_{\text {hitung }}$ untuk model regresi adalah 80,504 dengan tingkat signifikansi $0,000<0,05$ maka tingkat signifikansi model regresi lebih kecil dari taraf nyata. Hasil ini menunjukkan bahwa variabel-variabel bebas yaitu gaya kepemimpinan, lingkungan kerja dan stress kerja secara simultan mempunyai pengaruh signifikan terhadap variabel terikat yaitu kinerja pegawai. Kemudian besarnya nilai korelasi atau hubungan $(R)$ yaitu sebesar 0,915 yang mengandung pengertian bahwa hubungan variabel-variabel bebas (gaya kepemimpinan, lingkungan kerja dan stres kerja) dengan variabel terikat (kinerja pegawai) termasuk dalam kategori kuat. Besarnya persentase pengaruh variabelvariabel bebas terhadap variabel terikat yang disebut koefisien determinasi yang merupakan hasil dari penguadratan R. Dari output tersebut diperoleh koefisien determinasi ( $R$ Square) sebesar 0,837 yang mengandung pengertian bahwa besarnya pengaruh variabel-variabel bebas (gaya kepemimpinan, lingkungan kerja dan stress kerja) terhadap variabel terikat (kinerja pegawai) sebesar $83,7 \%$ sedangkan sisanya $17,3 \%$ dipengaruhi oleh variabel yang lain yang tidak diteliti didalam penelitian ini.

Hasil penelitian di atas di dukung oleh Penelitian Arianto (2013) dengan judul "Pengaruh Kedisiplinan, Lingkungan Kerja Dan Budaya Kerja Terhadap Kinerja Tenaga Pengajar". Jumlah sampel penelitian sebanyak 64 tenaga pengajar. Variabel yang diteliti ada 4, yaitu 3 variabel bebas yaitu kedisiplinan, lingkungan kerja, dan budaya kerja, dan 1 variabel terikat yaitu kinerja. Hasil yang diperoleh adalah lingkungan kerja tidak berpengaruh terhadap kinerja. Kemudian Penelitian Isnaini (2015) meneliti tentang "Pengaruh Lingkungan Kerja Dan Stres Kerja Terhadap Kinerja Karyawan (Studi Kasus pada PT Putra Nugraha Sentosa Mojosongo)." Sampel berjumlah 94 karyawan. Variabel yang diteliti ada 3, yaitu 2 variabel bebas 
yaitu lingkungan kerja dan stress kerja, dan 1 variabel terikat yaitu kinerja. Hasil yang diperoleh adalah lingkungan Kerja berpengaruh positif signifikan terhadap kinerja karyawan.

\section{F. KESIMPULAN DAN SARAN}

1. Kesimpulan

Berdasarkan hasil penelitian dan pembahasan yang telah diuraikan pada bab sebelumnya, dapat disimpulkan sebagai berikut.

a) Ada pengaruh yang signifikan Gaya Kepemimpinan terhadap Kinerja Pegawai Dinas Ketahanan Pangan dan Peternakan Kota Palembang. Berdasarkan hasil uji regresi sederhana menunjukkan bahwa nilai $t$ sebesar 4.218 dengan signifikansi 0,000 >0,05.

b) Ada pengaruh yang signifikan Lingkungan Kerja terhadap Kinerja Pegawai Dinas Ketahanan Pangan dan Peternakan Kota Palembang. Berdasarkan hasil uji regresi sederhana menunjukkan bahwa nilai $t$ sebesar 5.319 dengan signifikansi $0,000<0,05$.

c) Ada pengaruh yang signifikan Stres Kerja terhadap Kinerja Pegawai Dinas Ketahanan Pangan dan Peternakan Kota Palembang. Berdasarkan hasil uji regresi berganda menunjukkan bahwa nilai $t$ sebesar 3,037 dengan signifikansi $0,008<0,05$.

d) Ada pengaruh yang signifikan Gaya Kepemimpinan, Lingkungan Kerja dan Stres Kerja secara bersama-sama terhadap Kinerja Pegawai Dinas Ketahanan Pangan dan Peternakan Kota Palembang. Hasil uji Anova menunjukkan bahwa nilai $F_{\text {hitung }}$ untuk model regresi adalah 80,504 dengan tingkat signifikansi 0,000 $<0,05$ maka tingkat signifikansi model regresi lebih kecil dari taraf nyata. besarnya pengaruh variabel-variabel bebas (Gaya Kepemimpinan, Lingkungan Kerja dan Stres Kerja) terhadap variabel terikat (Kinerja Pegawai) sebesar $83,7 \%$ sedangkan sisanya $17,3 \%$ dipengaruhi oleh variabel yang lain yang tidak diteliti didalam penelitian ini.

\section{Saran}

Berdasarkan kesimpulan yang telah diuraikan, maka saran yang dapat peneliti sampaikan adalah sebagai berikut:

a) Hasil penelitian menunjukkan bahwa gaya kepemimpinan mempunyai pengaruh signifikan terhadap kinerja pegawai. Oleh karena itu, pimpinan hendaknya melakukan kajian ulang terhadap gaya kepemimpinan yang saat ini tengah berlangsung. Kajian ulang tersebut dilakukan dengan melakukan rapat bersama seluruh pegawai untuk menganalisa permasalahan dari masing-masing divisi, dengan membahas perihal beban kerja, apakah perlu penambahan staf pada beberapa divisi yang sebelumnya dipegang oleh satu orang. Sesuaikan jumlah pegawai dengan struktur organisasi yang ada. Berikan tanggung jawab pada 1 orang di setiap divisi untuk memimpin divisinya. Bagi para kepala bidang, tentukan deadline kerja pada setiap seksi-seksi di bawahnya dan luangkan waktu untuk memantau hasil kerja mereka tanpa harus memaksa pegawai bekerja seperti cara terdahulu selama itu tidak mengganggu atau mengacaukan data perusahaan yang sudah ada.

b) Untuk dapat meningkatkan kinerja pegawai, Dinas Ketahanan Pangan Dan Peternakan Kota Palembang diharapkan dapat menciptakan suasana yang menyenangkan, sehingga pegawai dapat bekerja dengan baik dan 
mendapatkan hasil kerja yang diharapkan.

c) Kepada pihak yang ingin melakukan penelitian sejenis, agar disarankan untuk meneliti variabel-variabel yang lain selain gaya kepemimpinan dan lingkungan kerja untuk menghindari adanya aktivitas plagiarism yang tentu saja melanggar etika penulisan skripsi

\section{DAFTAR PUSTAKA}

Edy, Sutrisno. (2011). Budaya Organisasi. Kencana Prenada Media Grup: Jakarta.

Hamali, A. Y. (2016). Pemahaman Sumber Daya Manusia. PT. Buku Seru: Yogyakarta.

Hasibuan, S, P. (2013). Manajemen Sumber Daya Manusia. PT. Bumi Aksara : Jakarta.

Nurhidaya, Siti. (2018). Pengaruh Lingkungan Kerja Terhadap Kinerja Karyawan (studi kasus CV. Fajar Nusantara jaya serangan. Surakarta) Skripsi Dipublikasikan. Fakultas Ekonomi Dan Bisnis Islam Institut Agama Islam Negeri Surakarta.

Oktariansyah, 2012. Pengaruh Kepemimpinan Dan Lingkungan Kerja Fisik Terhadap Motivasi Kerja Karyawan CV. Sedulur Palembang. Jurnal Media Wahana Ekonomika Vol. 9, No.2, Juli 2012 : 80 - 93

Prayatna dan Subudi. (2016). Pengaruh Gaya Kepemimpinan Terhadap Stres Kerja dan Kepuasan Kerja Karyawan Pada Fave Hotel Seminyak. Ejurnal.Manajemen Unud. Vol. 5 No.2 halaman 845.

Rahmi, Sari. Dkk. (2012). Pengaruh Kepemimpinan Dan Motivasi Stres Kerja Terhadap Kinerja Karyawan Pada Bank Syariah Mandiri Kantor Cabang Makasar. Jurnal Analisi. Vol. 1 No. 1 halaman 92.

Sudaryono. (2017). Pengantar Manajemen Teori Dan Kasus. PT. Buku seru: Yogyakarta.

Sugiyono. (2018). Metode Penelitian Manajemen. Alfabeta : Bandung

Sujarweni, V. Wiratna. (2019). Metodelogi Penelitian Bisnis \& Ekonomi. Pustaka Baru Press : Yogyakarta.

Wibowo. (2016). Manajemen Kinerja. PT. Raja Grapindo Persada : Jakarta. 